\title{
The Judges of Mecca and Mamluk Hegemony
}

\author{
John L. Meloy
}

\section{Introduction}

In his chronicle of the decades around the turn of the tenth/sixteenth century, the Meccan historian 'Izz al-Dīn Ibn Fahd recorded an anecdote in which two judges, the Ḥanbalī and Ḥanafĩ judges of Mecca, confronted a mamlūk amir, the famous Azbak al-Zāhirī, who was involved in a legal dispute over property in the Holy City. ${ }^{1}$ The judges accused Azbak of accepting a bribe to protect a claimant to the property and rebuked him: "Isn't it enough that you ruined Egypt and so now you come to ruin Mecca also?"2 By this time, in $902 \mathrm{AH} / 1497$, the Cairo Sultanate, of course, had had a long history in Mecca, and one would think that someone there would have thought, long before this moment, to comment on how the Sultanate's agents had affected the Hijaz. To me, this anecdote alludes to the implications of Cairo's influence in, rather than its direct control over, the Hijaz - an influence that ran deeper than the distant integration of political and fiscal offices in Mecca and Jedda into the Sultanate. After all, Azbak's reputation rather than the authority of his office was at play here. My goal in this chapter is to look beyond the establishment of these offices and what I have called elsewhere the "unruly" relationship between the sharifs and the sultan, in an effort to understand how the Cairo Sultanate perceived the problem of control in a periphery that, although physically very remote, was also symbolically very central to the state's viability. ${ }^{3}$ Here I will address the nature of the Sultanate's ideological domination and the extent to which it was achieved through hegemony - that is, dominance by means of the consent of the ruled, rather than by force ${ }^{4}$ - of the Hijaz, and especially of Mecca. I will argue that this entailed the centripetal transformation of a dis-

1 On Azbak, see Behrens-Abouseif, Azbakiyya.

2 'Izz al-Dīn ibn Fahd, Butūgh al-Qirā, 2: 981-982; 9 Jumādā II 902 AH (12 February 1497).

3 Meloy, Imperial Power.

4 Gramsci, Selections from the Prison Notebooks, passim. I have found useful discussions in: Bates, "Gramsci and the Idea of Hegemony", e.g., "political leadership based on the consent of the led, a consent which is secured by the diffusion and the popularization of the world view of the ruling class" (p. 352); and Williams, "The Concept of 'Egemonia", $586-589$. 
tant elite of jurists into stakeholders of the Sultanate, bringing the region more firmly into Cairo's sphere of ideological control.

The sharifs of Mecca and the sultans of Cairo had a relationship that operated on a number of occasionally intersecting political dimensions-rhetorical, administrative, and economic - that enhanced Cairo's hegemonic hold over Mecca. Because of the mutual dependence of Cairo and Mecca, the relationships were subject to change and negotiation..$^{5} \mathrm{Of}$ course, underlying this interdependence was Mecca's reliance on Egypt as a source for foodstuffs to maintain the populace of the Holy City, the ranks of which were swelled by the many pious sojourners who resided there often for long periods of time, and the even more numerous pilgrims who visited annually. ${ }^{6}$

The ideological claims of the Sultanate in Cairo are well known but it may be useful to sketch some of these features here since they form the background for later developments. ${ }^{7}$ Mecca became an object of political competition after the collapse of the Abbasid Caliphate at the hands of the Mongols in 1258 when the sultans of Egypt and Syria competed for influence in Mecca with the Rasulid sultans of Yemen and with the Ilkhans after their conversion. Cairo ultimately prevailed in these contests. The rhetorical claim of the Cairo sultans over the Hijaz dates back to the time of the Sultan al-Zāhir Baybars (r. 658-76 AH /1260-76), who claimed to be the protector of the two holy sanctuaries of Mecca and Medina, an arrangement formalized in a treaty between Sultan alManșūr Qalāwūn (r. 678-89 AH /1279-90) and Sharif Muhamammad Abū Numayy (r. 652-701 AH /1254-1301) of Mecca in $681 \mathrm{AH} / 1282,{ }^{8}$ and continued by Baybars's successors in Cairo until the end of the regime. This claim was expressed through a number of political rituals in Mecca: the invocation of the name of the Cairo sultan at the call to prayer and before the congregational sermon in the Harām Mosque in Mecca; the use of the title "Servitor of the Two Noble Sanctuaries", ${ }^{9}$ which asserted the sultan's role as preeminent Muslim

5 Meloy, Imperial Power. See also, for example, Barkey, Empire of Difference.

6 Mortel, "Mașādir al-Tamwīn", 193-219. On provisioning Mecca, also helpful is Suraiya Faroqhi, Pilgrims and Sultans, 164-166.

7 Jomier, Le Mahmal; idem, "Aspects politiques et religieux", 391-401.

8 Ibn 'Abd al-Ẓāhir, Tashrî́f al-Ayyām, 18-19; Ibn al-Furat, Tārīkh Ibn al-Furāt, 7:247-248; see also Melville, "Elephant", 197-214, esp. 198.

9 Combe, ed., Répertoire chronologique d'épigraphie arabe, 12:56-57, no. 4476, in Damascus dated 659/1261, and 12:103, no. 4554, in Kara (Qara ?) dated 664/1266. 
ruler; the annual dispatch of the cloth covering for the Ka'ba in Mecca; and the annual dispatch of the sultan's ceremonial palanquin, which represented the personage of the sultan. ${ }^{10}$

Cairo's dominance was also asserted administratively through the appointment of the sharifs as amirs in the Sultanate's administrative apparatus. Thus, in principle, the sharifs were subordinate to the sultans; however, this symbolic dominance did not necessarily give the Cairo sultans a free hand in the Hijaz. It was very much in the interests of the Cairo sultans to rule indirectly through the sharifs, whose lineage from the Prophet lent them an unassailable prestige and whose sway over local groups was often, but not always, an effective means to ensure free passage through the Hijaz for the pilgrimage and commerce. Hence the sharifs of Mecca were located at a nexus of local and interregional political and economic relationships which enabled them to serve as brokers whom the Cairo sultans could not do without. Noteworthy is the one instance, in $826 \mathrm{AH} / 1423$, in which the Cairo sultans replaced a ruling sharif, Hasan ibn 'Ajlān (r. 797-829 AH/1395-1426, with two interruptions), with an officer of the Sultanate, Qurqmās - not even ruling alone but appointed jointly with another sharif, 'Alī ibn 'Inān, a cousin of Ḥasan-whose joint appointment ended scarcely a year later with Hasan's re-instatement. ${ }^{11}$ At the same time, the sharifs did not have an entirely free hand in the Hijaz since the ruling sharif's position vis-à-vis local opponents - most often those claiming the sharifal successionwas enhanced by a political connection to Cairo. The combination of all these factors made for a rather contentious political system, most often characterized in Cairo as one of fitna. ${ }^{12}$

The two cities were also bound together as nodes in a network of longdistance trade that connected the continents, but their economic relationship was concretized fiscally when Sultan al-Ashraf Barsbāy (r. 825-41 AH/1422-38) set up a customs collection station in Jedda and established, at least for a time, increasingly tighter controls on commerce. Sources composed in Mecca offer more nuance to our understanding of these measures and allow us to appreciate that Mamluk political domination was not quite as relentlessly monolithic, and certainly not as inflexible, as it often appears to be in the official pronouncements of the Cairo Sultanate and in the narrative sources written in the Mamluk metropole. ${ }^{13}$

10 On the mahmal, see Jomier, Le Mahmal; idem, "Le mahmal du sultan Qansuh al-Ghuri", 183-188; and Meloy, "Celebrating the Mahmal", 404-427.

11 For a detailed account of this episode, see Meloy, Imperial Power, 115-125.

12 Meloy, Imperial Power, 95, 237.

13 Meloy, "Imperial Strategy", 1-19. 
In my previous work, although cognizant of these various dimensions of power, I focused on the dynamic and flexible quality of the Cairo-Mecca relationship, mainly through the process of brokerage; however, the end product was fundamentally an institutional history inasmuch as it explained how the Sharifate limited the Sultanate's power in the Hijaz periphery and how, in turn, the Hijazi socio-political order limited the ruling Sharif's power. Thus the judges' admonition is no less unsettling to me, since it is a reminder to consider both sides of Hodgson's ayān-amir system of social power (that is, the condominium of local civilian and military elites who, in the wake of centralized imperial power, dominated the Islamic lands in the later Middle Ages) in order to appreciate fully that influence may be as powerful as direct control and that ideas may rule as effectively as force. ${ }^{14}$ Consequently, one wonders what other, perhaps less visible, transformations were going on. Furthermore, although scholarly attention has been given to officials, civilian and otherwise, in the Hijaz, ${ }^{15}$ the judges' rebuke also serves as a pointed reminder that their storynot only as representatives, but also situated at the top of the civilian elite in a position perhaps parallel to Gramsci's intellectuals ${ }^{16}$ — has not yet been told. In order to attempt to rectify this situation, in this chapter I examine a community of judges and their role in the extension of Cairo's hegemony in Mecca, an effort that will take us back to the thirteenth and fourteenth centuries. This project provides an essential backdrop for understanding Mamluk state expansion in the Hijaz in the fifteenth century, and in particular the incorporation of elite groups in that region into the domain of the Cairo Sultanate, and for representing other features of the Mamlukization of the Hijaz-although ones that the two judges did not necessarily have in mind when they admonished amir Azbak.

To get immediately to the point, in addition to the dimensions of political engagement briefly outlined above, in the first half of the fourteenth century we see another manifestation of the Cairo Sultanate's hegemony in the Hijaz: the cooptation of judicial appointments which occurred during the principal reign

\footnotetext{
14 Hodgson, The Venture of Islam, 2: 64-69; Bates, "Gramsci", 351.

15 Mortel, "Aspects of Mamluk Relations", 1-13; idem, "The Decline of Mamluk Civil Bureaucracy", 173-188; idem, "Grand Dawadar", 437-456; idem, "The Mercantile Community", 15-35; Wing, "Indian Ocean Trade and Sultanic Authority", 55-75.

16 Petry, The Civilian Elite of Cairo, 227-228; Williams, "Gramsci's Concept", 587.
} 
of Sultan al-Nāṣir Muhammad (r. 709-41 AH/1310-41). In short, this was an effective means by which Cairo could extend its control through elite members of the civilian establishment in Mecca. My main source here is the biographical dictionary of Taqī al-Dīn al-Fāsī (d. $83_{2} \mathrm{AH} / 1429$ ), scion of a Meccan family who served as a Mālikī chief judge in the Holy City, supplemented by the works of Najm al-Dīn ibn Fahd (d. 885 AH/1480) and Shams al-Dīn al-Sakhāwī (d. 902 AH/1497). ${ }^{17}$ Al-Fāsī compiled biographies of over three thousand individuals, about 98 of whom are identified as judges. The biographies that date to the 150 years or so before his death are quite detailed and we can gather information about the ties that bound together the community of judges who served in Mecca, at least the Sunni ones, with whom the Cairo Sultanate was concerned. Al-Fāsī does not always supply details about appointments, but we can reconstruct the succession of those who served as the principal judge of Meccaalways of the Shäfi' madhhab - from the end of the seventh AH/thirteenth century until his time. Eight men held the position of chief judge in Mecca from $676 \mathrm{AH} / 1277-78$ through to the first decade of the ninth AH/fifteenth century, when the judicial hierarchy was modified, a subject to discuss below (see Table 7.1, judges \#2-\#9). A number of points are noteworthy about those who served in the fourteenth century.

First, the situation with judges in Mecca was very similar to that in the metropolitan centers of contemporary Egypt and Syria, where particular families (like the Bulqīn̄ss in Cairo and the Banū Jamāaa in Cairo and Damascus) dominated judicial positions. ${ }^{18}$ In Mecca also, local families dominated the judiciary. Prior to the mid-seventh AH/thirteenth century, judicial positions were dominated by other prominent families, such as the Shaybānī family, who subsequently became interrelated with the Tabarīs, so that the members often used both nisbas (as with 'Abd al-Karīm ibn Yahyā, judge \#o in Table 7.1). ${ }^{19}$ After the mid-seventh AH/thirteenth century, judicial positions in Mecca were dominated mainly by three families who intermarried. Most of the judges in the fourteenth century were from the al-Tabari and the al-Nuwayri families. In addition, during this time the Ibn Zahìra family also filled judicial positions along with a handful of others. In his study of the chief judges in Egypt, Joseph Escovitz designated four factors that played a role in judicial appointments: merit, patronage, nepotism, and succession through deputyships ( $n \vec{a} i b$

17 Al-Fāsī, al-Tqd; Najm al-Dīn ibn Fahd, al-Durr al-Kamīn; idem, Ithāa fal-Warā; al-Sakhāwī, al-Daw' al-Lāmic.

18 On the Bulqīnīs, see Petry, Civilian Elite, 232-240; on the Banū Jamāca, see Salibi, "The Banū Jamāea", 97-109.

19 Bauden, “Les Tabariyya”, 253-266. 
TABLE 7.1 Chief judges of Mecca from the mid-seventh AH/thirteenth century to the beginning of the ninth $\mathrm{AH} /$ fifteenth century with Hijri years of service

o. 622-645: 'Abd al-Karīm ibn Yahyyā al-Shaybānī al-Ṭabarī, Kamāl al-Dīn Abū Muhammad.

1. 645-673: 'Imrān ibn Thābit ibn Khālid al-Fihrī, Bahā' al-Dīn Abū Muhammad.

2. 673-675, 676-ca. 695: Muḥammad ibn Aḥmad al-Ṭabarī, Jamāl al-Dīn.

3. ca. $695-730:$ Muhammad ibn Muḥammad al-Ṭabarī, Najm al-Dīn Abū Hāmid.

4. $\quad$ 730-76o: Aḥmad ibn Muhammad al-Ṭabarī, Shihāb al-Dīn Abū al-Faḍl.

5. $\quad$ 76o-763: Muḥammad ibn Aḥmad al-Ḥarazī, Taqī al-Dīn Abū al-Yaman.

6. 763-786: Muḥammad ibn Aḥmad al-Nuwayrī, Kamāl al-Dīn Abū al-Faḍl.

7. 786-788: Aḥmad ibn Zahīra Ibn Zahīra, Shihāb al-Dīn Abū al-'Abbās.

8. 788-799: Aḥmad ibn Muḥammad al-Nuwayrī, Muhibb al-Dīn Abū al-Barakāt.

9. 799-8o6: Muhammad ibn Aḥmad al-Nuwayrī, 'Izz al-Dīn Abū al-Mafākhir.

appointments). ${ }^{20}$ While he determined that patronage played the largest role in appointments, he observed that nepotism and deputy succession were often combined and that the two factors together played the largest role. This was the situation that obtained in Mecca. Of course, these individuals were learned men; in the course of their early careers, they had travelled widely in pursuit of their studies: Medina, Cairo, Damascus, and Yemen figure most prominently as destinations. Nevertheless, personal connections clearly played a major role in their appointments. Of the eight chief judges, mentioned above, four were sons or grandsons of judicial predecessors and there were three connections to other judges through marriage (see Chart 7.1). Four individuals, at least, had served with predecessors as deputies (one of these did so with two predecessors), which parallels the pattern observed by Petry in Cairo, ${ }^{21}$ and at least four had studied with individuals who were judges in Mecca (see Chart 7.2).

20 Escovitz, "Patterns of Appointment", 147-168.

21 Petry, Civilian Elite, 228-229, 230. 


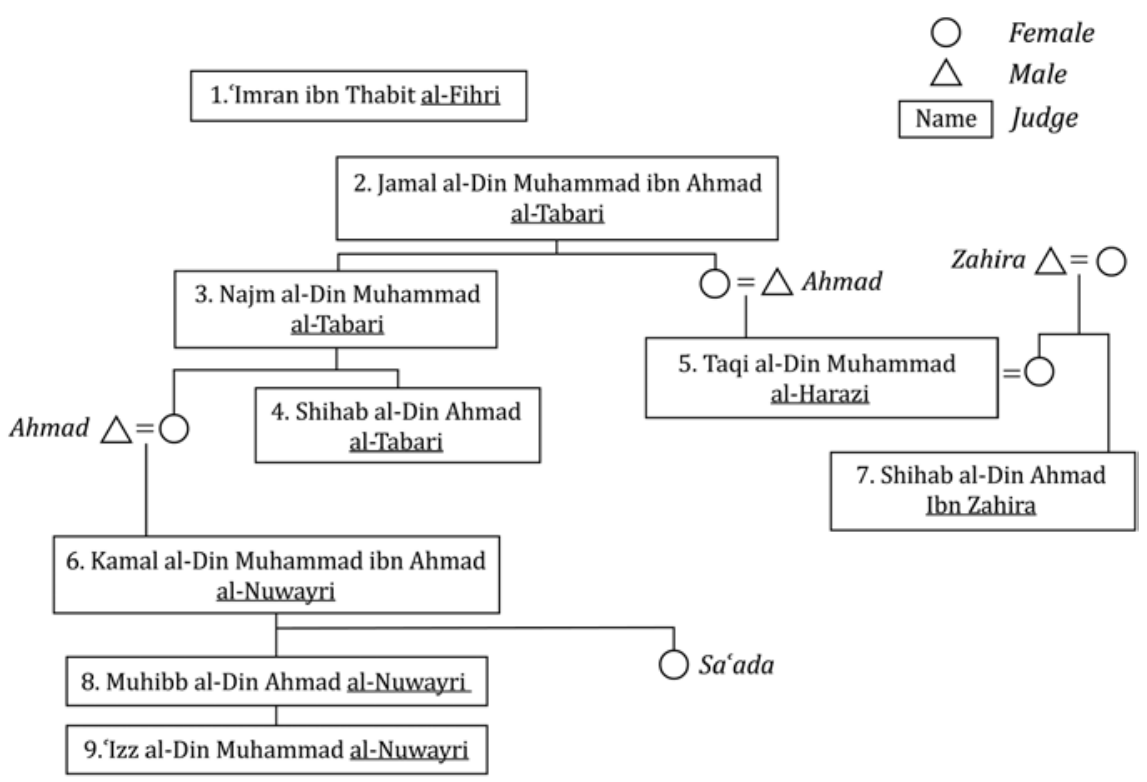

CHART 7.1 Chief judges of Mecca: Kinship

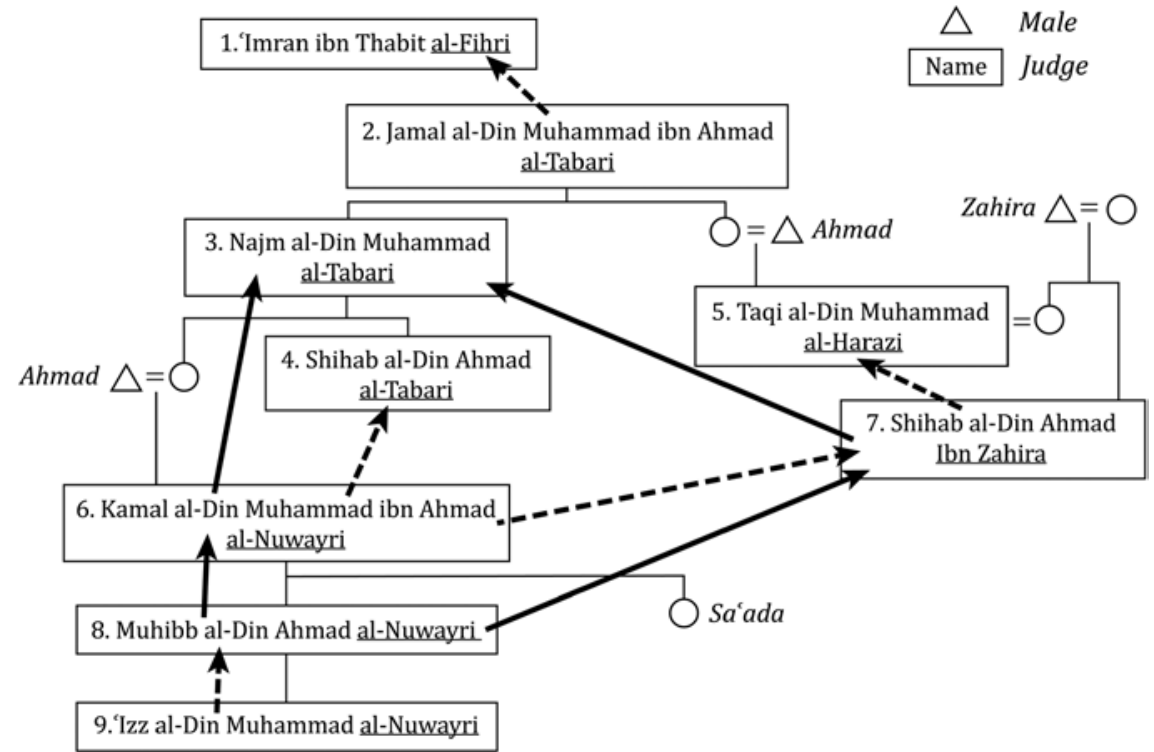

CHART 7.2 Chief judges of Mecca: Student-Teacher relationships (indicated with solid arrow) and service as deputy judge (indicated with dashed arrow) 
Second, it is important to note that up until the $730 \mathrm{AH} / 1330$ s the Rasulid sultans appointed the judges of Mecca. This was in spite of the claims of the earliest Cairo sultans to be the servitors of the Holy Cities. The sharif of Mecca, at least in one instance to be noted below, appointed a judge as well. There were evidently Zaydī judges, appointed by the Zaydī imam in Yemen, but we have little information: al-Fāsī mentions briefly one Zaydī judge from Yanbu', Aḥmad ibn Rashīd al-Yanbu'ī, who performed the pilgrimage in 819 AH/1416. Of course, as one would expect, al-Fāsī was chiefly concerned with Sunni judges; more information on the Zaydī judges would help us round out the picture. An interesting case is that of Jamāl al-Dīn Muhammad al-Ṭabarī (Chart 7.2, no. 2), who served as deputy to 'Imrān ibn Thābit al-Fihrī (no. 1), and then, after being appointed as judge, initiated a string of subsequent generations-either direct descendants or descendants through marriage - to hold the position. Al-Fāsī tells us that Jamāl al-Dīn voluntarily stepped down from the position (it is not explained why) in $675 \mathrm{AH} / 1276-77$, but that he was reappointed the following year by the Rasulid sultan, al-Muzaffar Yūsuf (r. 647-94 AH/1250-95), whereupon the judge duly resumed his responsibilities. However, the watershed moment in judicial appointments seems to have occurred with Jamāl alDīn's grandson, Shihāb al-Dīn Abū al-Faḍl Aḥmad al-Ṭabarī (Chart 7.2, no. 4), who held the position from $730-60 \mathrm{AH} / 1330-60$. He was initially appointed by the Meccan sharif, 'Uțayfa ibn Abī Numayy, and the appointment was confirmed later in the same year by the Rasulid sultan al-Mujāhid 'Alī (r. 721-64 $\mathrm{AH} / 1321-63)$. Two years later, in $73^{2} \mathrm{AH} / \mathbf{1 3 3}^{2}$, Shihāb al-Dīn received yet a third appointment as judge from the sultan al-Nāșir Muhammad, when the sultan performed the pilgrimage.

Given that the biographical and chronicle sources do not provide information to explain the policy behind the Cairo Sultanate's appointments, we can only draw some conclusions from the circumstantial evidence of the political context. The arrogation of judicial appointments occurred at the height of a competition for influence over the holy cities that was being waged between al-Nāṣir Muhammad and his political rivals, the Rasulids in Yemen and the Ilkhanids in Iran and Iraq. While the Rasulids had enjoyed considerable influence in the Hijaz, by the beginning of the fourteenth century they posed little military threat to Mecca, and no ideological claim over it, although the Yemeni sultans did try to extend their influence, by building institutions there and performing the pilgrimage, as will be noted below. The Ilkhans, however, directed a considerable amount of military and political capital toward the holy cities during the reigns of Muhammad Khudābanda Öljeytü (r. 703-16 AH/1304-16)

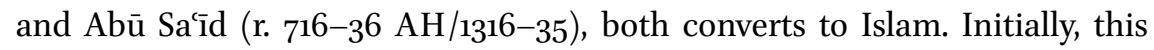
came about as political opportunity in the succession disputes that arose after 
the death of Sharif Abū Numayy (d. 701 AH/1301), which eventually led to an Ilkhanid military expedition in $716 \mathrm{AH} / 1316$ in alliance with the Sharif Humaydia ibn Abī Numayy. The putative objective of this force, at least according to Sunni readings of the mission, was to exhume the bodies of the Caliphs Abu Bakr and 'Umar from their graves in Medina and banish them from the Prophet's mosque in order to signal Öljeytü's rejection of their credibility as successors to the Prophet. ${ }^{22}$ However, upon receiving news of the death of Öljeytü (d. 716 AH/1316), the mission dissolved on its way to the Hijaz. Nevertheless, Sharif Humayda, together with the remnants of the Ilkhanid expedition, managed to enter Mecca after the departure of the Egyptian pilgrimage caravan, expelling his brother and rival Sharif Rumaytha ibn Abī Numayy, at the time the ruling sharif, from the city. They had the khuṭba given in the name of Öljeytü's successor, Abū Saīd, in Ṣafar 718 AH/April 1318. ${ }^{23}$ Humaydạ's hold on the city was short-lived, although the Cairo Sultanate's interests there were not yet secure.

The Ilkhans continued to pursue their interests in Mecca, although Abū Saìd adopted an approach less antagonistic than his predecessor's had been. In $723 \mathrm{AH} / 1323$, the two sides established a peace treaty although Abū Sa'ìd continued to try to boost his influence in Mecca through public works. For the pilgrimage of $730 \mathrm{AH} / 1330$, the Ilkhan sought to impress the faithful by sending his ceremonial palanquin (mahmal) on the back of an elephant. It was not a success: the poor animal died on the return journey and the one-upmanship only served to heighten tensions in Mecca, prompting al-Nāșir Muhammad to respond immediately with a military expedition in Șafar $731 \mathrm{AH} /$ November 1331. The next year, as mentioned above, he himself performed the pilgrimage (his third) during which he also issued the appointment of the Shäfi'i judge, Shihāb al-Dīn Abū al-Faḍl Aḥmad al-Ṭabarī, as mentioned above.

After the appointment of Shihāb al-Dīn, in the Meccan sources, there are no more reports of Yemeni judicial appointments, only Egyptian ones. Moreover, we also read of instances where the judges of Mecca worked in concert with the Cairo sultan. For example, when al-Nāșir Muhammad performed the pilgrimage, the judge Shihāb al-Dīn had the opportunity to ask the sultan about the validity of certain orders that were purportedly issued by his chancery. The sultan showed the judge a "mark" (amāra) that he could use to distinguish the authentic decrees, and Shihāb al-Dīn was consequently able to tear up fortysome forged documents. Judge Kamāl al-Dīn Abū al-Faḍl Muhạmmad al-Ṭabarī (Chart 7.2, no. 6), who had been Shihāb al-Dīn's deputy, prevented a powerful merchant, Zakī al-Dīn al-Kharrūbī, from paving the courtyard of the principal

22 Broadbridge, Kinship and Ideology, 128; Melville, "Elephant", 200-201.

23 Melville, "Elephant", 201. 
mosque in Mecca, al-Masjid al-Harām, saying that the only person with the authority to undertake this act was the sultan of Egypt. ${ }^{24} \mathrm{Al}$-Kharrūbī had real political clout: he was the commercial agent of the sultan and had clout with the Rasulid sultan al-Afḍal al-'Abbās (r. 764-78 AH/1363-77) due to his commercial interests in the Kārimī trade in luxury goods from south Asia. Kamāl al-Dīn paid dearly for crossing al-Kharrūbī. Kamāl al-Dīn was vulnerable to alKharrūbī's influential connections since the judge held concurrent appointments as the Shāfii professor in three prominent madrasas founded by Rasulid sultans: the Manșūiyya (founded $641 \mathrm{AH} / 1243-44)$, the Mujāhidiyya (founded $739 \mathrm{AH} /{ }_{1338-39)}$ ), and the Afḍaliyya (founded $768 \mathrm{AH} / 1366-67$ ). Al-Kharrūbī, in retaliation for the judge's rejection of his pious generosity, used his influence with the Rasulid sultan to have Kamāl al-Dīn dismissed from all three positions, by this time perhaps the only remaining domain of Yemeni influence in Mecca. ${ }^{25}$

Further developments occurred in the judicial hierarchy in the fifteenth century that show the imprint of Cairo's hegemony—-these will be examined in the penultimate section of this chapter. However, in order to focus on the nature of Cairo's hegemonic control over Mecca, it is important to first consider the sectarian disposition of the sharifs in the fourteenth century, which will be addressed in the following section. For now, we can conclude that the Sunni judges of Mecca were members of a discrete and clearly identifiable local social elite who were interrelated by blood and marriage ties and by their education and judicial training, and who, although they were born and bred in the Hijaz, were well travelled as a result of their cosmopolitan education. When al-Nāṣir Muhammad arrogated to himself the appointment of judges in Mecca, he not only absorbed into his state apparatus individuals who held prestige and authority and who worked in concert with his interests, but he also integrated into his state an entire regional social elite through their monopoly of Sunni figh: in effect, we see here the cooptation of an elite sector of society in Mecca. Other positions in the Meccan religious establishment as well as in other cities in the Hijaz need to be investigated as well, but it would appear to be a safe hypothesis that they were also similarly integrated.

The Sharifs and Conversion: Judges as Agents of Hegemony

The ideological claims of the Cairo sultans are often seen in the context of Cairo's competition with other great powers of the Islamic world: from India,

24 On al-Kharrūbī, see Wiet, "Marchands d'épice”, 114.

25 Al-Fāsī, Iqd 1: 300-307, no. 29. 
to Iran, to Yemen and North Africa. However, the sharifs of Mecca themselves, who followed Zaydī Shiite Islam, provided potential sectarian competition to the Sunni rulers of Egypt and Syria and their judges. The violence that the Cairo sultans inflicted on members of the Zaydì community in the Hijaz indicates that they considered this such a serious issue that they effectively expunged Zaydism from the local political leadership on Mecca, as Richard Mortel has argued. ${ }^{26}$ As I mentioned earlier, the Banu Ḥasan, who claimed descent from the son of 'Alì ibn Abī Ṭālib, ruled as sharifs of Mecca from the middle of the fourth/tenth century. They continued to rule in the Hijaz through the Ottoman period until the third decade of the twentieth century. However, the Sunni character of this lineage was a result of Cairo's imperial projection in the fourteenth century. I mentioned at the outset the first sharif of Mecca who had to deal with Cairo's claims on Mecca initiated by sultan al-Z̄āhir Baybars: Sharif Muhammad Abū Numayy. Muḥammad Abū Numayy, like his Banū Ḥasan forebears, was an ardent Zaydī, ensuring the practice of Zaydī rituals in the Great Mosque: for example, in the call to prayer, the Shici formula was used and, at the congregational prayer on Fridays, the Zaydis followed their practice of four rak'as of prayer rather than the Sunni tradition of two rak'as. Sharif Abū Numayy was highly admired for his political prowess with regard to his ability to fend off the ambitions of the sultans of Cairo and the Rasulids despite their pretensions to be the protectors of the two sanctuaries. Taqī al-Dīn al-Fāsī later wrote glowingly, tinged nevertheless with sectarian disapproval, of Sharif Abū Numayy that "were it not for his madhhab, he would have been [a] suitable [choice] for the Caliphate; [but] he was a Zaydī, as were his relatives". ${ }^{27}$

Mubārak ibn 'Uțayfa, himself of sharifian lineage, was reported by Ibn Faḍl Allāh al-'Umarī (d. 749 AH/1349) to have said about the sharifs of Mecca that they "profess their obedience for the Imam (the Zaydī imam of Yemen) and consider themselves his deputies. They are cautious with the ruler of Egypt out of fear and for the $i q t \bar{a}^{`}$ and with the ruler of Yemen for [the possibility] of bypassing them so that the Kârim [trade] continues [to come to Mecca] and [to obtain its] benefits". ${ }^{28} \mathrm{Al}$-Qalqāshandī (d. 821 AH/1418), writing at the turn of the fifteenth century, stated categorically in his chancery manual that the Banū Hasan of Mecca and Yanbu' were Zaydīs. ${ }^{29}$ However, the narrative sources would suggest that al-Qalqāshandī's information, at least about the sharifs of Mecca, was outdated - or perhaps there were lingering suspicions in Cairo of

26 For a detailed overview of the sharifs and religion, see Mortel, "Zaydi Shi'ism", $455^{-472 .}$ On Mecca during this period, see Ota, "The Meccan Sharifate", 1-20.

27 al-Fāsī, Iqd, 1: 467, no. 144; cf. Mortel, "Zaydī Shi' ism", 461-462.

28 Ibn Faḍl Allāh al-'Umarī, al-Ta'rīf, 203.

29 Mortel, "Zaydī Shi'ism", 467-468. 
the sharifs' convictions. Over the course of the fourteenth century, the sultan's officers used strong arm tactics and Cairo-appointed judges used aggressive moral pressure to drive Zaydism out of Mecca.

The politics of Mecca in the fourteenth century were as unruly as in the fifteenth century. In both centuries, the Cairo Sultanate added fuel to the fire of Sharifian rivalries. However, while Cairo's interests in the fifteenth century were driven by commercial concerns, in the fourteenth century, its interests were driven by competition with other Islamic powers, especially the Ilkhans, but also the Rasulids. The political history of the Hijaz in the first four decades of the fourteenth century was dominated by the rivalry of the four sons of Sharif Muhammad Abū Numayy, that led, in $714 \mathrm{AH} / 1315$, to the death of his son Abū al-Ghayth upon the orders of his brother Humayda, and a few years later, in $720 \mathrm{AH} / 1320$, to the murder of Humayda. Sharifs Rumaytha and 'Uțayfa continued to struggle over Mecca, and the former emerged as the victor. ${ }^{30}$ Just as they did in the fifteenth century, the Cairo sultans meddled in politics by using the force provided by the official pilgrimage caravan, led each year by the commander of the Egyptian pilgrimage caravan (amir al-hajj) and his military escort. During his political career, Rumaytha was removed from power and reinstated on four occasions. We see similar patterns of re-instatement over the following century with Rumaytha's son 'Ajlān, his grandson Ḥasan, and his great-grandson, Barakāt. ${ }^{31}$ The rulers of Cairo found that they had no other political options to sustain stability.

The narrative sources give occasional reports about Cairo's anti-Zaydi activities, which, taken in sum, may represent a sustained policy to diminish the prominence of Zaydism in the Hijaz or, at least, among the region's political elite. Cairo's pressure on the Zaydīs first occurred in $726 \mathrm{AH} / 1326$ when alNāṣir Muhammad sent a decree to 'Uțayfa ibn Abī Numayy, who was ruling sharif at the time, to forbid the Zaydi imam from leading prayers in the Masjid al-Harām. ${ }^{32}$ This decree, however, seems not to have been enforced, but the agents of the Sultanate subsequently became more aggressive. The next report comes twenty years later, in $746 \mathrm{AH} / 1346$, when Rumaytha died, to be succeeded initially by his son 'Ajlān, who occasionally had to compete for the paramount position with his brothers, Sanad, Thaqaba, and Mughāmis. The significant point here is that at Rumaytha's funeral the leader of the Zaydi community in Mecca, Ibn al-Shuqayf, stepped forward to lead the prayer, but he was prevented from doing so by the Shāfíi chief judge, Shihāb al-Dīn al-Ṭabarī (who, as

30 Mortel, al-Aḥwāl, 65-9o.

31 Meloy, Imperial Power, 102-112, 142-162.

32 Al-Fāsī, 'Iqd, 6: 98, no. 2003. 
noted earlier, was appointed by Sultan al-Nāșir Muhammad), who went on to lead the service. ${ }^{33}$

Less than a decade later, in $754 \mathrm{AH} / 1353^{-54}$, during the brief reign of alṢāliḥ Ṣālih (r. 752-5 AH/1351-4), the sultan's agents took more severe measures to prevent the practice of Zaydism in Mecca. The Cairo-based Abbasid Caliph al-Mu'tadidid (r. 753-63 AH/1352-62) and the Shāfi'i chief judge of Cairo, 'Izz alDīn 'Abd al-'Aziz ibn Jamā'a, performed the pilgrimage that year along with an unusually large number of prominent amirs. ${ }^{34}$ The goals of this delegation were twofold: to establish Sunnism at the expense of Zaydism and to counter Yemeni ambitions in Mecca. In $75^{1} \mathrm{AH} / 1351$, the Rasulid al-Mujāhid 'Alī performed the pilgrimage, evidently at the encouragement of Thaqaba, supported by his brothers Sanad and Mughāmis, who hoped that with the Yemeni ruler's assistance they could drive their brother 'Ajlān out of Mecca. The plot failed, the conspiring brothers fled to the south, and the Yemeni sultan was captured by the agents of Cairo but eventually released. ${ }^{35}$ While these sharifian intrigues were going on, the Egyptian agents continued their persecution of Zaydīs in Mecca. The Zaydī imam in Mecca, Abū al-Qāsim Muhammad ibn Aḥmad alYamanī, was beaten and imprisoned for refusing to renounce his faith. Until this time, Abū al-Qāsim had held a prominent role in the Masjid al-Harām, where he led his community in prayer and had a specially designated pulpit. He subsequently managed to escape the city; however, his associate, the Zaydī muezzin, was not as fortunate since the Egyptian pilgrimage commander had him beaten to death. ${ }^{36}$ 'Izz al-Dīn ibn Jamā'a remained in Mecca for some months after the pilgrimage and then the following Ramaḍan convened a meeting with the leader of the Zaydīs, Ibn al-Shuqayf-this is the man who was prevented from leading the prayers at the funeral of Sharif Rumaytha about a decade before. Ibn Jamā'a persuaded him "to renounce, [in writing,] before God most high, the creed of the Zaydī, Imamī, and other heretics" (itiqād ahl al-bida' al-zaydiyya al-imamiyya wa-ghayrihā). Al-Fāsī noted candidly that Ibn al-Shuqayf acquiesced because he was afraid that he would meet the same fate the muezzin had met only a few months before. ${ }^{37}$

33 Al-Fāsī, Iqd 3: 161-166, no. 647; 4: 417, no. 1196.

34 Najm al-Dīn Ibn Fahd, Ithāa al-Warā 3: 261; al-Maqrī̄ī, Kitāa al-Sulūk, 2: 903; al-Sakhāwī, al-Dhayl al-Tāmm, 1: 134; on ibn Jamā‘a, see Salibi, "Banu Jamā'a", 101-102.

35 For details and sources on this, see Mortel, al-Ahwāl, 96-97; De Gaury, The Rulers of Mec$c a, 101$.

36 Ibn Fahd, Ithāa al-Warā, 3:260-262; Maqrīīì, Kitāb al-Sulūk, 2:904.

37 Al-Fāsī, 'Iqd, 8:89-9o, no. 2975; Ibn Fahd, Ithāaf al-Warā 3:265. Note that Mortel says that al-Fāsī remarked that Ibn al-Shuqayf agreed upon his own volition (Mortel, "Zaydī 


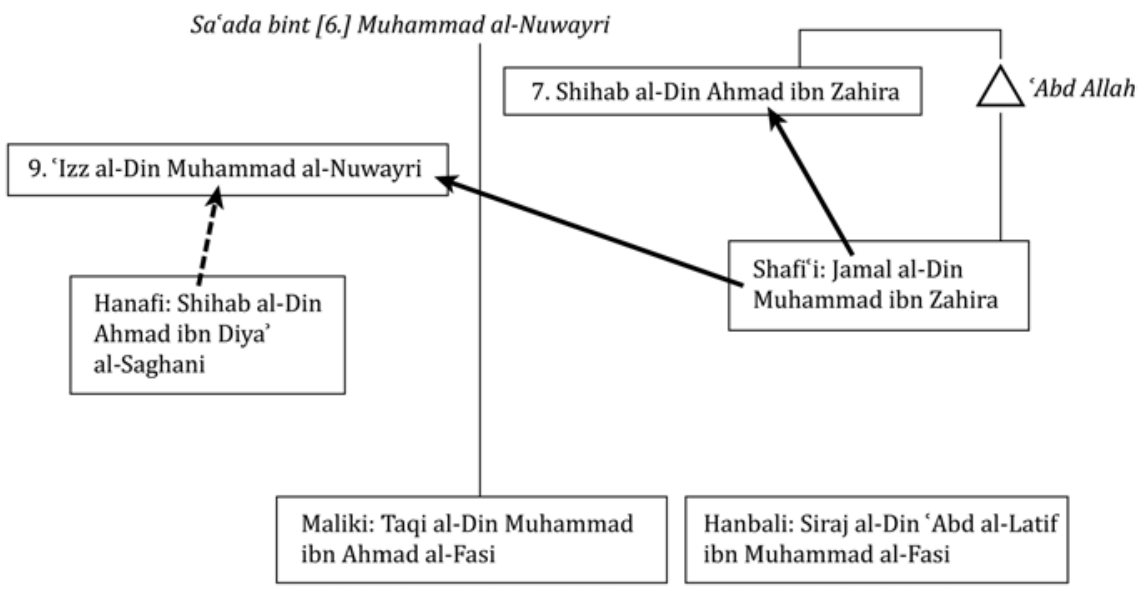

CHART 7.3 The first chief judges of Mecca for the four Sunni schools of law

Al-Fāsī wrote that when 'Ajlān was on his deathbed in $777 \mathrm{AH} / 1375$ he requested that the Sunni judge of Mecca, Kamāl al-Dīn Abū al-Faḍl Muhammad alNuwayrī, the maternal grandfather of al-Fāsī (Chart 7.2, no. 6; and Chart 7.3) and the judge who was dismissed from professorships in the three Rasulid madrasas, supervise his funeral with the Sunni fuqah $\bar{a}$, signifying the sharif's last assertion of Sunnism. ${ }^{38}$ However, it is noteworthy that the transition from Zaydism to Sunnism among the ruling sharifs may not have been abrupt: even 'Ajlān, as a Sunni, did not retain his title as the Cairo sultan's amir of Mecca. He was replaced by his brothers Sanad and Thaqaba, both of whom, we are told by al-Fāsī, adhered to their Zaydism. 'Ajlan was subsequently re-appointed in 763 $\mathrm{AH} / 1362$. Thus the Cairo sultans extended their hegemony in the region through these parallel approaches: carrying out aggressive anti-Zaydī actions and coopting the Sunni judicial community. But their ideological goals were also tempered with pragmatism, so their control of the ruling sharif was more important to them than the ruling sharif's faith. Finally, while the Cairo Sultanate was ultimately successful in their ideological domination of Mecca, by no means was Zaydism eradicated from the region. Other members of the Banū Hasan, like those in Yanbu', continued to avow their Zaydism but they became increasingly marginalized..$^{39}$

Shi' ism", 466, citing Al-Fāsī, Iqd 8:89-9o) but the evidence for this conclusion is not clear to me.

38 Al-Fāsī, 'Iqd 6: 70, no. 1979.

39 Hurgronje noted that, during his time, "in the environs of Mekka there are still strong remains of that Shi'itism which once contributed to the conquest of western Arabia by the Sherifs, and is now for its reward despised by them". Mekka, 199-200. 
'Ajlān seems to have been pragmatic as well, professing Sunnism in order to win the support of Cairo. ${ }^{40}$ Certainly, he was the last of his generation to rule, and it would seem that with him and his descendants Sunnism was unquestionably established in the Sharifal family. Both 'Ajlān and his son and principal successor Ḥasan endowed madrasas to teach Shāfi'i fiqh in Mecca. 'Ajlān's son Ḥasan as well as his sons, Barakāt, 'Alī, Abū al-Qāsim, and Ibrāhīm, all of whom ruled Mecca into the mid-fifteenth century, all studied hadith with Sunni scholars. ${ }^{41}$ It must be said that the Sunnism of these men did not ensure political stability, in spite of their effective consent to Cairo's hegemony over the political leadership of Mecca. Meccan politics continued to be highly contentious due to the political dynamics of tribal society in the Hijaz and, if anything, the contention increased in the first half of the fifteenth century when trade is mentioned more often. However, the sharifs' acceptance of Sunnism and their efforts to educate their sons accordingly must have facilitated their relations with the Sultanate's officialdom as well as with the Cairo-appointed chief judges of Mecca.

\section{Back to the Judges in the Fifteenth Century}

In the fifteenth century, we start to see two more developments. First, we see the judicial hierarchy and its operation conforming to that of the rest of the Cairo Sultanate. Second, we discern connections between judges and sharifs that indicate the comfortable cohabitation of these two local elites. During the reign of the Sultan Faraj ibn Barqūq (r. 801-808 AH/1399-1405), the number of chief judges in Mecca increased fourfold since he took the decision to appoint chief judges of the Sunni madhhabs in Mecca, an arrangement, of course, established by Sultan Baybars in Cairo in the $1260{ }^{42}{ }^{42}$ But the local and highly interconnected nature of the Hijazi judicial leadership did not change. The first Shāfíi appointed in this new system (see Chart 7.3) was Jamāl al-Dīn Muhammad ibn Zahīra, who had studied with his immediate predecessor, 'Izz al-Dīn Muhammad al-Nuwayrī and with Shihāb al-Dīn Aḥmad ibn Ẓahīra, his relative, who had preceded 'Izz al-Dīn as judge. ${ }^{43}$ In 807 AH/1404-05, the

40 Hurgronje (ibid.) called the sharifs "opportunists in the question of rite". This seems an unfair judgment on the sharifs in general; however, 'Ajlān's actions suggest that he may well qualify.

41 Najm al-Dīn ibn Fahd, al-Durr al-Kamīn 1:591, no. 514; 1:647, no. 563; 2:1015, no. 992; 2:1329, no. 1404; al-Sakhāwī, al-Paw' al-Lāmic 3:13, no. 50; 3:104, no. 417; 5: 211, no. 709. On this development, see Escovitz, "The Establishment of Four Chief Judgeships", Jackson, "The Primacy of Politics", 52-65; and Rapoport, "Legal Disunity", 210-228. Al-Fāsī, 'Iqd, 2: 53-59, no. 213; 1: 371-376, no. 47; 3: 52-53, no. 562. 
first Ḥanafĩ judge, Shihāb al-Dīn Aḥmad al-Ṣāghānī, had also served as deputy to 'Izz al-Dīn Muḥammad al-Nuwayrī. ${ }^{44}$ The first Mālikī judge, Taqī al-Dīn Muhammad al-Fāsī, the author of our main source for the eighth AH/fourteenth century, was the grandson of Kamāl al-Dīn Abū al-Faḍl al-Nuwayrī (Chart 7.2, no. 6; and Chart 7.3).45 Two years later, in $809 \mathrm{AH} / 1406-07$, the first Hanbali judge was appointed - Sirāj al-Dīn 'Abd al-Lațîf ibn Abī Fatḥ Muḥammad alFāsī, a second cousin of Taqī al-Dīn al-Fāsī, his Mālikī colleague. ${ }^{46}$

Seemingly in parallel to the appointment of chief judges was the establishment, for the first time in Mecca, of a madrasa that taught the four Sunni schools of law. The Banjaliyya Madrasa, also known as the Ghiyāthiyya, was founded in $813 \mathrm{AH} / 1410$ by Ghiyāth al-Dīn A'ẓam Shāh (r. 792-813 AH/139o1410), the sultan of Bengal. Its four professors of the madhhabs were, at least initially, the four chief judges appointed by the sultan in Cairo. It was not unusual for judges to hold teaching positions, as was the case with the chief judges' illustrious predecessor, Kamāl al-Dīn Abū al-Fạ̣l Muhammad al-Nuwayrī (Chart 7.2, no. 6), noted earlier, who held three positions simultaneously. Nothing had changed in this regard and nothing had changed in terms of the network that facilitated appointments to judicial positions. Of course, what is interesting here is the extension of Indian influence into the mix, which, if anything, ended up supporting Cairo's hegemony; but after all, the Indian regimes often appealed to the Abbasid Caliph in Cairo for recognition.

In addition, just as individuals bought judicial positions in Egypt and Syria, so too did judicial aspirants in Mecca, at least in the fifteenth century when we have evidence for this in local sources, although this didn't necessarily preclude the necessity of personal connections that ensured succession in judicial appointment. During the time when the Mamluk officer Jānibak al-Ẓāhirī dominated Mecca in the 86os AH/1465-64, Muhibb al-Dīn ibn Zahīra was appointed Shāfiì chief judge to succeed his deceased father, after he paid Jānibak 2,500 dinars, in addition to "some books". The amount appears to have been a bargain compared to the 10,000 dinars for a chief judgeship in Damascus in

\footnotetext{
44 Al-Fāsī, Iqd, 3: 168-170, no. 650.

45 Al-Fāsī, 'Tqd, 1: 331-363, no. 38.

46 Sakhāwī, al-Daw 'al-Lämi' 3: 333-334, no. 923: he was the second cousin of al-Fāsī: "he was the grandson of the paternal uncle of the father of Taqī al-Dīn al-Fāsī”. Among his teachers was Shihāb al-Dīn ibn Zahīra. Al-Sakhāwī also says (4:333): "his father was a Mālikī but he changed to the Hanbali madhhab and he was appointed imam of the Hanbalīs in Mecca after the death of the son of his paternal uncle al-Nūr 'Alī ibn 'Abd al-Lațîf ibn Aḥmad, then to the judgeship in 809 and he was the first Hanbali to be appointed to a judgeship of Mecca".
} 
$876 \mathrm{AH} / 1471$ (of course, comparison of the figures here is very difficult). ${ }^{47}$ Muhibb al-Dīn was replaced a year later, in $862 \mathrm{AH} / 1457-8$, by his nephew, Burhān al-Dīn ibn Zahīra; it's not stated if he paid for the office. However, it is reported that Burhān al-Dīn remained in office until his death, in $892 \mathrm{AH} / 1487$, when his son Jamāl al-Dīn ibn Ẓahīra, succeeded him. Jamāl al-Dīn paid Sultan al-Ashraf Qāytbāy (r. 872-901 AH/1468-1496) 10,000 dinars, 3,000 of which were owed by his father and 7,000 for his own appointment. ${ }^{48}$

We also start to see connections between sharifs and chief judges. Although the judges were interrelated through marriage, they seem not to have intermarried with the sharifs. I have found only one instance of this: Sharif Hasan ibn 'Ajlān was married to the half-sister of Taqī al-Dīn al-Fāsī. One way, however, that the sharifs and judges were tied together was through the distribution of alms. Although there were now four chief judges, the Shäfic chief judge, as in Cairo, still held greater prestige and responsibility, which included responsibility for oversight of the public treasury, pious endowments, and orphans. ${ }^{49}$ One feature of this position in Mecca was in the distribution of alms (șadaqa) which arrived every year from rulers abroad, ranging from the Ottomans in Anatolia, to the Tahirids of Yemen, to the sultans of India..$^{50}$ The Shāfi' chief judge supervised the distribution of alms following a customary division which granted the ruling sharif of Mecca one third of the sum. One instance, dated 20 Shawwāl $888 \mathrm{AH} / 21$ November 1483 , is typical:

[On Shawwal 20] the Shāfiī judge Burhān al-Dīn [ibn Zahīra], may God bless him for it, distributed șadaqa for Ramaḍān from al-Khaljī [of Mālwa, Ghiyāth al-Dīn Shāh ibn Maḥmūd (r. 873-906 AH/1469-1501)], at the hand of his messenger Yahyaa, amounting to four hundred ashrafis. Sayyid Muhammad ibn Barakāt took one third of it, as customary, according to what I heard, and [Burhān al-Dīn] bestowed on the judges five, and the preachers four, and the religious officials and the remaining [significant] people $(a l-n \bar{a} s)$ two, one, two-thirds, one-half and one-third, extending [even] to many of the foreigners, which was not customary, but it appeared that he had a reason for that, but God alone knows. ${ }^{51}$

Najm al-Dīn ibn Fahd, Ithāf al-Warā 4:370-372; for the comparison, see Martel-Thoumian, "The Sale of Office", 75, whose study deals with a later period.

48 Najm al-Dīn ibn Fahd, Itḥāf al-Warā 4: 381; 'Izz al-Dīn ibn Fahd, Bulūgh al-Qirā 1: 479-48o.

49 Jackson, "Primacy of Domestic Politics", 53.

$5^{0}$ In fact, this practice may have occurred even earlier; however, we only have evidence for the second half of the fifteenth century.

51 'Izz al-Dīn ibn Fahd, Bulūgh al-Qirā, 1: 313 . 
More often, the author, Najm al-Dīn ibn Fahd, would indicate where he stood in this hierarchy of largesse. A number of the gifts were more substantial, amounting to thousands or even tens of thousands of dinars which placed the Shāfici judge in a key position, in terms of his relationship to the sharif and as patron to the religious elite in Mecca. ${ }^{52}$

Yet one should be cautious in assuming that the relationship between the sharif and the Shāfíi judge was purely pecuniary and instrumental in nature. These men, the judges and the sharifs going back to the time of Hasan ibn 'Ajlān, were tied together by similar educational backgrounds. Sharif Muhammad ibn Barakāt, like his father and grandfather, Ḥasan, had studied Shāfíi fiqh not only in Mecca, but also in Cairo and Damascus. ${ }^{53}$ From 862 AH/1458 until the death of Sharif Muhammad in $903 \mathrm{AH} / 1497$, the Shāfici chief judgeship was held by the aforementioned Burhan al-Dīn ibn Zahīra and his son Jamāl al-Dīn. Both judges enjoyed close friendship with Sharif Muhammad. Najm al-Dīn ibn Fahd observed that the sharif and Burhan al-Dīn had a "firm friendship" and that "with his friendship [with Burhan al-Dīn,] the Sayyid obtained abundant blessings" ${ }^{54}$ 'Izz al-Dīn Ibn Fahd's narrative noted frequently that the Sharif participated in Ibn Zahīra family celebrations for marriages and circumcisions, and when Sharif Muhammad was dying, Jamāl al-Dīn visited his older friend to offer his support. ${ }^{55}$ So these men were tied together through common background as members of the class of notables with shared interests.

Nevertheless, such a bond between sharif and judge could also work to their detriment. About ten years after the death of Sharif Muhammad and about five years after the occurrence of the anecdote I mentioned concerning the amir Azbak, shared interests brought together Sharif Aḥmad al-Jāzānī, one of the warring sons (yet again) of Sharif Muhammad and the judge Abū al-Su'ud ibn Zahīra. At this time, Barakāt ibn Muḥammad had been waging a vicious war against his brother Aḥmad al-Jāzānī for control of Mecca as ruling sharif. Barakāt found letters from the judge Ibn Zahīra revealing his support for the cause of Ahmad. The messages from the judge urged the latter to take over Mecca and drive out Barakāt. Barakāt's men captured the judge, stripped him of his possessions, and took him to the island of Qunfidha off the Hijazi coast where he was drowned. ${ }^{56}$ Clearly, a judicial appointment counted for little in the context of Meccan politics.

\footnotetext{
52 For a discussion of these instances, with citations, see Meloy, Imperial Power, 191-197.

53 Najm al-Dīn ibn Fahd, al-Durr al-Kaminn, 1:103-121, no. 70.

54 Najm al-Dīn ibn Fahd, al-Durr al-Kamīn, 1:612, no. 524.

55 'Izz al-Dīn ibn Fahd, Bulügh al-Qirā 2:1019; for a brief discussion of the context, see Meloy, Imperial Power, 196.

$5^{6}$ 'Izz al-Dīn ibn Fahd, Bulūgh al-Qirā, 2:1210; al-Sinjārī, Manāih al-Karam, 3:114-127.
} 
Noteworthy is that these families of judges, along with the Banū Hasan themselves, were coopted by Cairo just as Cairo coopted the power of the pilgrimage, the wealth of the trade routes, and the authority of the sharifs. In this regard, the Sultanate's state possessed a kind of "legibility", that is, an ability "to arrange the population in ways that simplified the classic state functions of taxation, conscription, and prevention of rebellion", to quote James Scott, in an effort "to shape a people and landscape that will fit their techniques of observation". ${ }^{57}$ The legibility of the pre-modern state is, I would argue, shortchanged by Scott, who claims that it "knew precious little about its subjects, their wealth, their landholdings and yields, their very identity". ${ }^{5}$ In response, one might at first think of the Cairo Sultanate's encyclopedic chancery manuals or the detailed compilations of cadastral data produced by Ibn Duqmāq (ca. 797 AH/1395) and Ibn al-jīann (d. 885 AH/1480). The difference, it would appear to me, at least with regard to the Cairo Sultanate is that the modes of control were not even relatively simpler, but just simply different. In the context of the Hijaz, Cairo read the social landscape with reasonable accuracy and used a variety of means to integrate the local Sunni judicial elite into the Sultanate's legal apparatus, which served to overcome, if only partially, the distance between Cairo and Mecca.

The Sunni judges of Mecca (and presumably also those who worked in the other cities of the Hijaz) seem to have been willing to be incorporated into the Sultanate's political structure. At the administrative level, the sharifs of Mecca were also willing to be incorporated into the state hierarchy, at least superficially, using their association with Cairo to their own local political advantage. This bureaucratic stratagem, evincing a form of legibility, was both expedient and effective as a means of control within the interplay between Cairo and Mecca. However, there was quite a different situation at the ideological level because the sharifs_-as Zaydīs_-posed a serious threat to Cairo. The sharifs threatened, first, the security of the state as potential allies to the Ilkhans and,

57 Scott, Seeing Like a State, 2-3 and 82.

58 Scott, Seeing Like a State, 2. One problem is that his concept of legibility is based on the historical category of "high modernism"; in this respect, the concept doesn't work in other eras. Another issue is that his definition relies on Foucault's "governmentality" which assumes the state's interest in improving members of society (p. 91) or simply the notion that states are supposed to serve their citizens. Nevertheless, I think Scott's notion of how states "see" is useful; in the context of the fifteenth century, how and what states "saw" was different. 
second, the credibility of the Cairo Sultanate as ideological adversaries to a Sunni regime. Here, to achieve hegemony, the Cairo Sultanate used selective violence against Zaydī officials and simultaneously exploited sharifian rivalries to achieve their political objectives in the Hijaz.

Was Cairo's control over the Hijaz in the fifteenth century reliant on the extension of hegemony in the preceding century? It is clear that the Cairo Sultanate's hegemony over Mecca preceded its political control and may well have facilitated it, just as Egypt's economic hegemony over the Hijaz must have restricted the autonomy of local elites. Egypt's cultural and social hegemony allowed political domination of the Hijazi elite to function more effectively and, one can surmise, at less cost to Cairo. In spite of the ability of the Cairo Sultanate to read the social and political landscape of the Hijaz, the sultans could not achieve either direct control or hegemony over the tribal groups that lived there, thus they relied on the local political order of the sharifs.

Finally, to return to legibility, when the judges rebuked Azbak- "you've ruined Egypt, you want to ruin Mecca too?"- they were evidently blind to the fact that Mecca had been Mamlukized long before amir Azbak's arrival, and that they, as part of the local elite, were part and parcel of that process.

\section{Bibliography}

\section{Primary Sources}

Al-Fāsī, Taqī al-Dīn Muḥammad ibn Aḥmad, al-Tqd al-Thamīn fì Tảīkh al-Balad alAmīn, 8 vols., Muhammad al-Ṭayyib Ḥāmid al-Fiqqīe et al., eds. (Cairo: Maṭbáat alSunnah al-Muhammadiyya, 1959-69).

Ibn 'Abd al-Ẓāhir, Muhyī al-Dīn, Tashrīf al-Ayyām wa-l- Ușūrfísìrat al-Malik al-Manșūr,

Murād Kāmil, ed. (Cairo: Wizārat al-Thaqāfa, 1961).

Ibn al-Furat, Nāṣir al-Dīn Muhammad, Tārīkh Ibn al-Furāt, vol. 7, Constantine Zurayk, ed. (Beirut: American Press, 1942).

Ibn Faḍl Allāh al-Umarī, Shihāb al-Dīn Aḥmad, al-Tarīî bi-l-Musțalah al-Sharīf, Muhammad Ḥusayn Shams al-Dīn, ed. (Beirut: Dār al-Kutub al-Ilmiyya, 1988).

Ibn Fahd, 'Izz al-Dīn 'Abd al-'Azīz, Bulūgh al-Qirā fìDhaylIthāa al-Warā bi-Akhbār Umm al-Qurā, Salāḥ al-Dīn ibn Khalīl Ibrāhīm, et al., eds., 4 vols. (Cairo: Dār al-Qāhira, 1425/2005).

Ibn Fahd, Najm al-Dīn 'Umar ibn Muḥammad, al-Durr al-Kamīn bi-Dhayl al-Tqd alThamin fi Ta'rïkh al-Balad al-Aminn, 'Abd al-Malik ibn 'Abd Allāh ibn Duhaysh, ed., 3 vols. (Mecca: Maktabat al-Asadī, 1425/2004).

Ibn Fahd, Najm al-Dīn 'Umar ibn Muḥammad, Ithāa al-Warā bi-Akhbār Umm al-Qurā, Fahīm Muhammad Shaltūt, ed., 5 vols. (Mecca: Jāmi'at Umm al-Qurā, 1983-90). 
al-Maqrīzī, Taqī al-Dīn Aḥmad, Kitāb al-Sulūk li-Márifat Duwal al-Mulūk, Muḥammad Muhammad Ziyāda and Sā̄ì 'Abd al-Fattāḥ 'Āshūr, eds., 4 vols. (Cairo: Lajnat alTa'lif wa-al-Tarjama wa-l-Nashr, 1956-73).

Al-Sakhāwī, Shams al-Dīn Muḥammad ibn 'Abd al-Raḥmān, al-Dạw' al-Lāmi' li-Ahl alQarn al-Tāsí, 12 vols. (Bulaq, n.d.).

Al-Sakhāwī, Shams al-Dīn Muḥammad ibn 'Abd al-Raḥmān, al-Dhayl al-Tāmm 'alā Duwal al-Islām, Hasan Ismāōil Muruwwa, ed., 3 vols. (Beirut: Dār Ibn al-'Imād, 1992).

Al-Sinjari, 'Alī, Manāiḥ al-Karam fì Akhbār Makka wa-l-Bayt wa-Wulāt al-Haram (Mecca: Jāmi'at Umm al-Qurā, 1998).

\section{Secondary Sources}

Barkey, Karen, Empire of Difference: The Ottomans in Comparative Perspective (Cambridge: Cambridge University Press, 2008).

Bates, Thomas R, "Gramsci and the Idea of Hegemony", Journal of the History of Ideas 36/2 (1975): 351-366.

Bauden, Frederic, "Les Tabariyya: Histoire d'une importante famille de la Mecque (fin $\mathrm{XII}^{\mathrm{e}}-$ fin $\mathrm{XV}^{\mathrm{e}}$ s.)", in U. Vermeulen and D. de Smet, eds., Egypt and Syria in the Fatimid, Ayyubid, and Mamluk Eras (Leuven: Peeters, 1995), pp. 253-266.

Behrens-Abouseif, Doris, Azbakiyya and Its Environs (Cairo: Institut français d'archéologie orientale, 1985).

Broadbridge, Anne F., Kinship and Ideology in the Islamic and Mongol Worlds (Cambridge: Cambridge University Press, 2008).

Combe, Étienne, et al., eds., Répertoire chronologique d'épigraphie arabe, vol. 12. (Cairo: Institut français d'archéologie orientale, 1953).

De Gaury, Gerald, The Rulers of Mecca (London: George G. Harrap and Co., 1951).

Escovitz, Joseph, "The Establishment of Four Chief Judgeships in the Mamluk Empire”, Journal of the American Oriental Society 102:3 (1982): 529-531.

Escovitz, Joseph, "Patterns of Appointment to the chief Judgeship of Cairo during the Bahri Mamluk Period", Arabica 30 (1983): 147-168.

Faroqhi, Suraiya, Pilgrims and Sultans: The Hajj under the Ottomans (London: I.B. Tauris, 1994).

Gramsci, Antonio, Selections from the Prison Notebooks, Q. Hoare and G. Nowell Smith, ed. and trans. (New York: International Publishers, 1971).

Hodgson, Marshall G.S., The Venture of Islam: History and Conscience in a World Civilization, vol. 2 (Chicago: University of Chicago Press, 1974).

Hurgronje, C. Snouck, Mekka in the Latter Part of the 1gth Century, J.H. Monahan, trans. (Leiden: Brill, 2007).

Jackson, Sherman, "The Primacy of Domestic Politics: Ibn Bint al-A'azz and the Establishment of Four Chief Judgeships in Mamluk Egypt", Journal of the American Oriental Society 115/1 (1995): $5^{2-65}$. 
Jomier, Jacques, Le Mạ̣mal et la caravane égyptienne des pèlerins de la Mecque XIII ${ }_{-}$ $X X^{e}$ siècles (Cairo: Institut français d'archéologie orientale, 1953).

Jomier, Jacques, "Aspects politique et religieux du pèlerinage de la Mekke", in Livre du Centenaire, 1880-1980 (Cairo: Institut français d'archéologie orientale, 1980), pp. 391-401.

Jomier, Jacques, "Le maḥmal du sultan Qansuh al-Ghuri (début XVI ${ }^{\mathrm{e}}$ siècle)", Annales islamologiques 11 (1972): 183-188.

Martel-Thoumian, Bernadette, "The Sale of Office and its Economic Consequences during the Rule of the Last Circassians (872-922/1468-1516)", Mamlük Studies Review 9 (2005): 49-83.

Meloy, John L., "Imperial Strategy and Political Exigency: The Red Sea Spice Trade and the Mamluk Sultanate in the Fifteenth Century", Journal of the American Oriental Society $123 / 1$ (2003): 1-19.

Meloy, John L., "Celebrating the Mahmal: The Rajab Festival in Fifteenth Century Cairo", in Judith Pfeiffer et al., eds., History and Historiography of Post-Mongol Central Asia and the Middle East: Studies in Honor of John E. Woods (Wiesbaden: Harrassowitz Verlag, 2006), pp. 404-427.

Meloy, John L., Imperial Power and Maritime Trade: Mecca and Cairo in the Later Middle Ages (Chicago: Middle East Documentation Center, 2010).

Melville, Charles, “The Year of the Elephant': Mamluk-Mongol Rivalry in the Hejaz in the Reign of Abū Sa'īd (1317-1315)", Studia Iranica 21 (1992): 197-214.

Mortel, Richard T., al-Aḥwāl al-Siyāsiyya wa-l-Iqtișādiyya bi-Makka fì l-'Așr al-Mamlūkī (Riyadh: Jāmi'at al-Malik Sa'ūd, 1985).

Mortel, Richard T., "Mașādir al-Tamwīn al-Ghadhāī li-Imārat Makka (359/969923/1517)", Majallat Kulliyat al-Ādāb, Jāmi'at al-Malik Sa'ūd 12/1 (1985): 193-219.

Mortel, Richard T., "Zaydi Shi'ism and the Hasanid Sharifs of Mecca", International Journal of Middle East Studies 19/4 (1987): 455-472.

Mortel, Richard T., "The Mercantile Community of Mecca during the Late Mamluk Period", Journal of the Royal Asiatic Society (3rd. ser.) 4/1 (1994):15-35.

Mortel, Richard T., "Aspects of Mamluk Relations with Jedda during the Fifteenth Century: The Case of Timraz al-Mu'ayyadi" Journal of Islamic Studies 6/1 (1995): 1-13.

Mortel, Richard T., "The Decline of Mamluk Civil Bureaucracy in the Fifteenth Century: The Career of Abū al-Khayr al-Nahhas", Journal of Islamic Studies 6 (1995): 173-188.

Mortel, Richard T., "Grand Dawadar and Governor of Jedda: The Career of the Fifteenth Century Mamluk Magnate Ganibak al-Zahiri”, Arabica 43:3 (1996): 437-456.

Ota, Keiko, "The Meccan Sharifate and Its Diplomatic Relations in the Bahri Mamluk Period", Annals of the Japan Association for Middle East Studies 17/1 (2002): 1-20.

Petry, Carl F., The Civilian Elite of Cairo in the Later Middle Ages (Princeton: Princeton University Press, 1981). 
Rapoport, Yosef, "Legal Disunity in the Age of Taqlid", Islamic Law and Society 10 (2003): 210-228.

Salibi, Kamal, "The Banū Jamāaa: A Dynasty of Shāfi'ìte Jurists in the Mamluk Period", Studia Islamica 9 (1958): 97-109.

Scott, James C., Seeing Like a State (Yale: Yale University Press, 1998).

Wiet, Gaston, "Marchands d'épice", Cahiers d'histoire égyptienne 7 (1955): 81-147.

Williams, Gwyn, “The Concept of 'Egemonia' in the Thought of Antonio Gramsci: Some Notes on Interpretation", Journal of the History of Ideas 21:4 (1960): 586-589. Wing, Patrick, "Indian Ocean Trade and Sultanic Authority: The nazir of Jedda and the Mamluk Political Economy", Journal of the Economic and Social History of the Orient 57 (2014): 55-75. 